\title{
Antibodies reacting with Simian Virus 40 capsid protein mimotopes in serum samples from patients affected by uveal melanoma
}

Ilaria Bononi ${ }^{1 \dagger}$, Paolo Perri ${ }^{2 \dagger}$, Alice Begnardi ${ }^{1}$, Alessandra Martini ${ }^{2}$, Elisa Mazzoni ${ }^{1}$, Silvia Bosi ${ }^{1}$, Silvia Pietrobon $^{1}$, Adolfo Sebastiani ${ }^{2}$, Mauro Tognon ${ }^{2^{*}}$ and Fernanda Martini ${ }^{2^{*}}$

\begin{abstract}
The uveal melanoma (UM) is the most common human intraocular tumour. Simian Virus 40 (SV-40) is a small DNA tumor virus detected in some malignancies, including the cutaneous melanoma. In this study an indirect ELISA using synthetic peptides that mimic SV-40 antigens, was employed to detect antibodies against SV-40 in serum samples from UM patients. Our report indicates a significant higher prevalence of antibodies against SV-40 capsid protein antigens in serum samples from UM patients compared to controls. Our data suggest an association between UM and SV-40, indicating that patients affected by uveal melanoma tested SV-40-positive could be treated by innovative therapies.
\end{abstract}

Keywords: Uveal melanoma, Simian Virus 40, ELISA, Antibody, Prevalence

\section{Findings}

The uveal melanoma (UM) is the most common primary intraocular tumor. Many studies reported genetic alterations in UM [1], but the causes are poorly understood. BAP1, a gene encoding a deubiquitinant enzyme, is mutated in several UM cases and in the malignant pleural mesothelioma (MPM) [2], a human tumour found be associated with the Simian Virus 40 (SV-40) infection $[3,4]$. SV-40 oncogenic potential has been demonstrated in experimental animals [3,4], while its mutagenic activities have been detected in different animal and human cell types $[3,4]$. In human tumours, SV-40 was identified for the first time in a patient affected by a cutaneous melanoma [5], that shares the onset model with UM. Altogether these data were the background that prompted us to investigate the association between UM and SV-40 by analysing the prevalence of SV-40 antibodies in serum samples from UM affected patients. This study was carried out, as reported before, by an indirect Enzyme-Linked Immunosorbent Assay (ELISA) with SV-40 specific

\footnotetext{
* Correspondence: tgm@unife.it; mrf@unife.it

${ }^{\dagger}$ Equal contributors

${ }^{2}$ Department of Biomedical Sciences and Surgical Specialities, School of Medicine, University of Ferrara, Via Luigi Borsari 46, Ferrara 44121, Italy
}

Full list of author information is available at the end of the article synthetic peptides derived from its viral proteins, without cross-reactivity with the closely related BKV and JCV which are obiquitous polyomaviruses in humans [6].

In this investigation, serum samples from UM affected patients $(\mathrm{n}=48)$ and healthy subjects with ocular nevi (HSON; $\mathrm{n}=71$ ) and without ocular nevi (HS; $\mathrm{n}=168$ ), with the same median age (66 yrs), were analysed for presence of SV-40 antibodies. All patients and subjects were vaccinated against the poliomyelitis. The immunologic study was carried out by indirect ELISAs employing two specific mimotopes from SV-40 viral capsid proteins 1 and $2-3$, named $B$ and $C$ peptides, respectively [6]. In our experiments, serum samples were considered SV-40 VPpositive upon reacting to both peptides B and C. Informed written consent was obtained from the patients and subjects. The study was approved by the County Ethical Committee, Ferrara, Italy.

The overall prevalence, by combining SV-40-positive sera for both VP1 B and VP2/3 C peptides, in UM patients was $33 \%$, higher than that detected in HSON or HS, $17 \%$ and $15 \%$ respectively. The difference between UM patients and HSON or HS is statistically significant $(\mathrm{p}=0.038$ and $\mathrm{p}=0.004$, respectively). Serologic profiles of serum antibody reactivity to SV40 mimotopes are reported in Figure 1. The difference of $\mathrm{OD}=$ optical density 


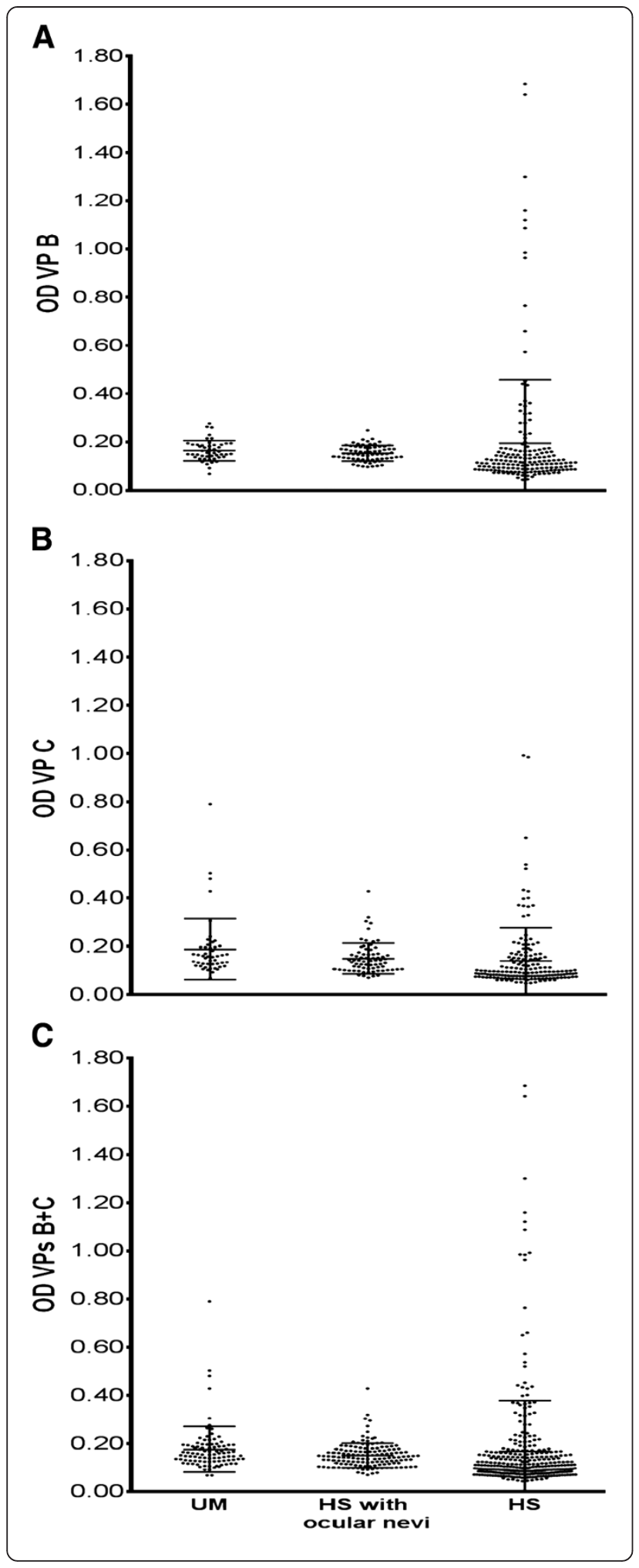

Figure 1 Serologic profile. Serologic profile of serum antibody reactivity to SV-40 mimotopes VP1 B (panel A) and VP2/3 C (panel B) and VPs B $+C$ (panel C). Immunologic data are from patients affected by UM and from healthy individuals (HS) with and without ocular nevi. Data are OD values at $405 \mathrm{~nm}$ of serum samples diluted 1:20, detected in indirect ELISA. In scatter dot plotting, each plot represents the dispersion of OD values to a mean level indicated by the line inside the scatter with standard error mean (SEM) for each group of subjects analyzed (Mean OD \pm SEM).

mean value of sera from UM and two control groups, is not statistically significant $(\mathrm{p}>0.05)$.

Our immunologic data indicate that a subset $(1 / 3)$ of UM is associated with SV-40, a small DNA tumour virus detected as a contaminant in early anti-polio vaccines $[3,4,7]$. At present, SV-40 infection seems to spread in humans by different ways, including the urine and the faecal-oral route $[3,4,7]$.

UM onset, like other human cancers, is due to specific gene mutations. Since SV-40 is oncogenic, clastogenic, mutagenic and a transforming viral agent [3,7], may be a risk factor, together with other oncogenic agents such as the U.V. irradiation, in the UM onset/progression [8]. One may postulate that after infecting the host, SV-40 may exert its tumourigenic potential when the immune system is impaired. The high prevalence of SV-40 antibodies in sera from UM affected patients is not proof of cause/effect in inducing human tumours by SV-40. SV40 DNA and expression of its oncogene, the large T antigen, should be analysed in UM specimens to confirm and extend the potential role of this oncogenic virus in UM onset/progression. We should also consider, as an alternative explanation, that another not yet discovered human Polyomavirus closely related to SV-40 may be responsible of our immunologic data. Our results from the laboratory bench could be transferred to the clinical application employing specific innovative therapies for SV40-positive UM patients.

\section{Competing interests}

The author declare that they have no competing interests.

\section{Authors' contributions}

TM, SA and MF designed the study and secured funding; MF, TM, PP and SA given final approval of the version to be published; PP, MA and BS collected samples; PP and SA performed the clinical diagnosis; BI, BS and BA conducted the experimental work; $B I, B A, M F$ and TM analysed the data and wrote the manuscript; ME and PS gave support in analysis of data and statistics; MF and TM made the final critical revision. All authors read and approved the final manuscript.

\section{Acknowledgments}

Dr. Elisa Mazzoni is a post doctoral fellow of the Fondazione Veronesi, Milan, Italy.

We would like to thank Dr. Eugene O. Major, the Laboratory of Molecular Medicine and Neuroscience, the National Institute of Neurological Disorders and Stroke, Bethesda, MD, for the hyperimmmune serum against JCV.

Supported, in part, by grants from University of Ferrara, FAR projects, Ferrara and PRIN 2008, from MIUR, Rome. Italy. All authors actively contributed to this work. 


\section{Author details}

'Department of Morphology, Surgery and Experimental Medicine, School of Medicine, University of Ferrara, Via Fossato di Mortara 64/b, Ferrara 44121, Italy. ${ }^{2}$ Department of Biomedical Sciences and Surgical Specialities, School of Medicine, University of Ferrara, Via Luigi Borsari 46, Ferrara 44121, Italy.

Received: 19 March 2014 Accepted: 18 April 2014

Published: 29 April 2014

\section{References}

1. Onken MD, Worley LA, Long MD, Duan S, Council ML, Bowcock AM, Harbour JW: Oncogenic mutations in GNAQ occur early in uveal melanoma. Invest Ophthalmol Vis Sci 2008, 49:5230-5234.

2. Testa JR, Cheung M, Pei J, Below JE, Tan Y, Sementino E, Cox NJ, Dogan AU, Pass HI, Trusa S, Hesdorffer M, Nasu M, Powers A, Rivera Z, Comertpay S, Tanji M, Gaudino G, Yang H, Carbone M: Germline BAP1 mutations predispose to malignant mesothelioma. Nat Genet 2011, 43:1022-1025.

3. Martini F, Corallini A, Balatti V, Sabbioni S, Pancaldi C, Tognon M: Simian virus 40 in humans. Infect Agent Cancer 2007, 2:13.

4. Butel JS: Patterns of polyomavirus SV40 infections and associated cancers in humans: a model. Current opinion in virology 2012, 2:508-514.

5. Soriano F, Shelburne CE, Gokcen M: Simian virus 40 in a human cancer. Nature 1974, 249:421-424.

6. Corallini A, Mazzoni E, Taronna A, Manfrini M, Carandina G, Guerra G, Guaschino R, Vaniglia F, Magnani C, Casali F, Dolcetti R, Palmonari C, Rezza G, Martini F, Barbanti-Brodano G, Tognon MG: Specific antibodies reacting with simian virus 40 capsid protein mimotopes in serum samples from healthy blood donors. Hum Immunol 2012, 73:502-510.

7. Barbanti-Brodano G, Sabbioni S, Martini F, Negrini M, Corallini A, Tognon M: $B K$ virus, JC virus and Simian Virus 40 infection in humans, and association with human tumors. Adv Exp Med Biol 2006, 577:319-341.

8. Griewank KG, Yu X, Khalili J, Sozen MM, Stempke-Hale K, Bernatchez C, Wardell S, Bastian BC, Woodman SE: Genetic and molecular characterization of uveal melanoma cell lines. Pigment cell \& melanoma research 2012, 25:182-187.

doi:10.1186/1756-8722-7-38

Cite this article as: Bononi et al: Antibodies reacting with Simian Virus 40 capsid protein mimotopes in serum samples from patients affected by uveal melanoma. Journal of Hematology \& Oncology 2014 7:38.

\section{Submit your next manuscript to BioMed Central and take full advantage of:}

- Convenient online submission

- Thorough peer review

- No space constraints or color figure charges

- Immediate publication on acceptance

- Inclusion in PubMed, CAS, Scopus and Google Scholar

- Research which is freely available for redistribution 